University of St. Thomas, Minnesota

UST Research Online

2000

\title{
Strategic HR configurations and organizational performance
}

Mick A. Sheppeck Ph.D.

University of St. Thomas - Minnesota, masheppeck@stthomas.edu

Jack F. Militello Ph.D.

University of St. Thomas - Minnesota, jfmilitello@stthomas.edu

Follow this and additional works at: https://ir.stthomas.edu/ocbmgmtpub

Part of the Business Administration, Management, and Operations Commons

This Article is brought to you for free and open access by the Management at UST Research Online. It has been accepted for inclusion in Management Faculty Publications by an authorized administrator of UST Research Online. For more information, please contact asle4660@stthomas.edu. 
This material was reproduced by permission of the rightsholder via Copyright Clearance Center, Inc.

\title{
STRATEGIC HR CONFIGURATIONS AND ORGANIZATIONAL PERFORMANCE
}

\author{
Michael A. Sheppeck and Jack Militello
}

Over time organizations form stable operating configurations that influence their actions in the marketplace. These configurations are shaped in interactions among variables in four areas: operating environment, business strateg; HRM practices, and senior managers' values and behaviors regarding employees. More often than not they emerge in a piecemeal rather than planned fashion. However, once established, the configurations or patterns guide employee behavior, are resistant to change, and are associated with different levels of organization effectiveness. HR managers may' use these configurations to diagnose their organizations' present state and orchestrate changes to increase competitive advantage. (C) 2000 John Wiley \& Sons, Inc.

\section{Introduction}

Human resource management (HRM) issues have often been missing from the strategic management process in many organizations (Tichy, Fombrun, \& DeVanna, 1982). In place of strategy, the procedures of personnel administration have often dictated how organizations deal with their people resources. This emphasis on operationally oriented tools and procedures has slowed the development of human resource management as a contributor to strategic business planning and fostered a mindset among many human resource professionals that the latest practice or concept to capture senior management attention is the practice of choice in any given situation. In effect, administration or fashion rather than strategy is often the engine that drives HRM practices in organizations.

On the other hand, the strategy concept, as it articulates an organization's strengths/ weaknesses and threats/opportunities being faced, has been well described in business planning (Andrews, 1987). In this context, strategy deals with choices regarding how an organization's marketplace activities are configured to gain competitive advantage. Mintzberg (1989) described strategy as encompassing both overt plans for future actions and patterns that implicitly evolve from past practices. Realized strategies are those patterns that have actually emerged from past practices. Intended strategies, conversely, are formal plans and pronouncements for future actions designed to produce competitive advantage.

The concept of strategy has recently received increased attention in HRM as well (Delery \& Doty 1996). If it could be articulated, an organization's HRM strategy would often be described as a patchwork quilt (i.e., derived from sundry and sometimes random inputs). Schuler and Jackson (1989) noted that "researchers are now beginning to ask how
In effect. administration or faslizion rather than strategy is often the erzinize that drives HRII practices in organizations. 
TABLEI Basic Alignment Principles.

1. An organization's long-term effectiveness requires at least minimal alignment among four components:

- environment (i.e., market context),

- marketplace strategy;

- HRI practices,

- management support for people.

2. The relationships among the components are unstable with some interests in competition with each other at various times.

3. Over time in successful organizations the components align to form an enduring theme or pattern that informs employee behavior.

4. Constant vigilance and resolution of trade-offs among the components are required to create alignment in an ever-changing context.

5. Greater degrees of alignment result in more effective organization goal attainment.

6. A finite number of workable alignment patterns exist for any given organization at any particular point in time.

7. It is possible to determine an appropriate alignment pattern for an organization and to move toward that state.

Organizations focusing ont customer intinuacy are dedicated to providing unique solutions and services to fit customers' needs. services to fit customers' needs. These firms cultivate deep knowledge and relationships with their customers in an effort to provide high-value customized offerings. They tend to promote employee empowerment to achieve better customer contact, develop measures around customer commitment and loyalty, and cultivate a "hav'e it your way" culture. The value chain becomes reversed in these organizations in that the systemic nature associated with customer intimacy drives the internal business design.

The authors noted that successful organizations do not simply focus on one discipline and abandon the other two. Rather they choose one of the value dimensions and build their organization and marketplace reputation around it over the long term.

\section{HRM Practices}

Various authors have identified a range of strategic HRM practices. Delery and Doty (1996) noted that strategic HRM practices are "those that are theoretically or empirically related to overall organization performance" (p. 805). They identified seven practices as fitting this definition: internal career opportunities, formal training systems, appraisal measures, profit sharing, employment security, employee voice mechanisms, and job design. Youndt et al. (1996) focused on the dual themes of enhancing employee skills via staffing/development and employee empowerment through voice mechanisms/job design while Delaney and Huselid (1996) classified HRM practices according to their impact on employee shills, motivation, and work design features. as strategic HRM categories. Other authors have also included employee ownership, general information sharing, symbolic egalitarianism/status differentiation (MacDuffie, 1995: Pfeffer, 1994), the use of dispute resolution processes (Arthur, 1992: Huselid, 1995), attitude assessment, and labor/ management participation (Delaney, Lewin, \& Ichniowski, 1989) as strategic HRM practices.

We focused on a broad array of HRM practices grouped into four strategic HRM dimensions: (1) employee skills and work policies, (2) supportive enrironment, (3) performance measurement and reinforcement, and (4) market organization (see Table II). These dimensions generally reflect the HRM practices defined respectively by Ulrich and Lake (1990) as generating, sustaining, and reinforcing competencies, and also reflect aspects of the Delery and Doty (1996) market-type employment system.

\section{Management Support for HRM}

We defined the leadership variable as senior management support for HRM activities and 
the ability to fit HRM strategies into the overall purpose of the firm. Specifically, we included such senior management behaviors as stating a clear philosophy regarding the importance of human resources to the organization's purpose, continually investing resources to improve HRM practices, and including $H R$ executives in planning and decision making. Results from a Society for Human Resource Management/ Commerce Clearing House study showed that this variable influenced the relationship between organizational strategy and the outcomes of organizational productivity and market/book value (CCH Inc., 1995).

\section{Perceived Organization Effectiveness}

We defined organization effectiveness using the model presented by Quinn and Rohrbaugh

\section{TABLEII Strategic HRM Dimensions.}

1. Employee Skills and Work Policies/Practices Purpose: Identify and develop superior performing employees

- Staffing

- Training

- Work design

- Employee relations practíces

2. Supportive Environment Practices Purpose: Foster sustained employee motivation

- Employee empowerment

- Employee assistance

- Diversity

- Flexible benefits

3. Performance Measurement and Reinforcement Practices

Purpose: Focus employees' energies on specific productive behaviors

- Performance appraisal

- Compensation

t. Market Organization Practices

Purpose: Create a linkage between employees and the organization

- Alternative work design

- Compensation

- Market Leading Compensation
(1983), which focuses on resource acquisition, operational efficiency: product/service quality, change capability; coordination. and development of human resources.

\section{Strategic HRM Configurations}

Our observations of firms from various industries suggest that several configurations regularly occur in the organizational landscape (see Tables III and IV for patterns and example organizations). The initial two configurations are associated with mediocre organizational effectiveness and financial outcomes while the final three tend to result in above average sustained performance.

\section{Combination}

This configuration is comprised of organizations competing in a moderately dynamic environment (i.e., customer bases, modes of competition, prices, and/or technology within a market that tend to shift on a yearly or biennial basis) using a combination of operational excellence and product leadership competitive strategies. The attempted combination of these two value disciplines often results in employee ambiguity regarding strategic priorities. This competitive strategy ambiguity is typically associated with a tepid emphasis on HRM practices. In particular, these organizations tend to place little emphasis on finding and developing exceptional talent while utilizing employee outsourcing through temporary agencies for high-volume job families such as assemblers, technicians, and clerks. At the same time, they engage in employee involvement diversity, appraisal, and rewards-forperformance programs that often exist for several years and are then either canceled or revised and then re-promoted. The lukewarm emphasis on sustained HRM initiatives relates to a lack of support by senior management for people as a competitive advantage and to the complexity of simultaneously supporting both operational excellence and product leadership market strategies.

Our experiences suggest these organizations are found in both the manufacturing and service industries and in small, intermediate, and large firms (in terms of employees). Typically their performance in

\author{
We defined tire \\ leadership \\ variable as senior \\ management \\ sitpport for HRM \\ activities and the \\ ability to fit \\ HRM strategies \\ into the overall. \\ purpose of the \\ firm.
}


TABLE III Observed Configurations.

\begin{tabular}{|c|c|c|c|c|c|}
\hline & Combination & $\begin{array}{l}\text { Classic } \\
\text { Operations }\end{array}$ & $\begin{array}{l}\text { Emerging } \\
\text { Operations }\end{array}$ & $\begin{array}{l}\text { Classic } \\
\text { Product Leader }\end{array}$ & $\begin{array}{l}\text { Classic } \\
\text { Customer }\end{array}$ \\
\hline Entironment & Moderately & $\begin{array}{l}\text { Stable } \\
\text { Dynamic }\end{array}$ & Stable & Dỹnamic & Very Dynamic \\
\hline $\begin{array}{l}\text { Competitive } \\
\text { Strategy }\end{array}$ & $\begin{array}{l}\text { Operational } \\
\text { Excellencel } \\
\text { Product Leader }\end{array}$ & $\begin{array}{l}\text { Operational } \\
\text { Excellence }\end{array}$ & $\begin{array}{l}\text { Operational } \\
\text { Excellence }\end{array}$ & Product Leader & $\begin{array}{l}\text { Customer } \\
\text { Intimacy }\end{array}$ \\
\hline \multicolumn{6}{|l|}{ HRMI Practices } \\
\hline Find \& Develop & Low: & Very Low & Very High & High & Very High \\
\hline $\begin{array}{l}\text { Supportive } \\
\text { Environment }\end{array}$ & Moderate & Very Low & Very High & Very High & High \\
\hline Reinforce & Noderate & Very Low & High & Very High & High \\
\hline Mlarket Focus & Moderate & Very Low & Noderate & High & Moderate \\
\hline $\begin{array}{l}\text { Management } \\
\text { Support for } \\
\text { HRM }\end{array}$ & Low & Very Low & Very High & High & High \\
\hline Effectiveness & Moderate & Low & High & High & High \\
\hline Industry & $\begin{array}{l}\text { Manufacturing/ } \\
\text { Serice }\end{array}$ & Service & Manufacturing & Manufacturing & Service \\
\hline $\begin{array}{l}\text { Size } \\
\text { (employees) }\end{array}$ & Small to Large & Small & $\begin{array}{l}\text { Intermediate } \\
(<500)\end{array}$ & $\begin{array}{l}\text { Intermediate } \\
(500-5,000)\end{array}$ & $\begin{array}{l}\text { Small to Large } \\
(500-5,000)\end{array}$ \\
\hline
\end{tabular}

Our experiences support the notion that man? manufacturing firms have initiated leadership, work design, organization structure, and HRM interventions to compete in the next centur? while many service fims lag behind regarding these changes. the areas of resource acquisition, operational efficiency, product/service quality, change, coordination, and development of human resources is mediocre as is their financial performance compared to other organizations in their industries.

\section{Classic Operations}

These organizations are characterized by a very stable environment (i.e., on a year-to-year basis almost unchanging customer bases, modes of competition. prices, and use of technology within a market). strong use of the operational excellence strateg: very little emphasis on the four HRM practices, and very little support from senior management for HRM issues. Nanagers in these organizations often view their firms as struggling to compete and are sometimes confused regarding the strategic changes needed to turn the organization around. Daily operations in these firms are driven by clear standard operating practices that provide a substitute for motivation via leadership or enriched work designs, by clear organizational purpose, and by honest tradeoffs among configuration components. While some of the firms we studied in this configuration are in the manufacturing sector, most are service-related organizations.

Our experiences support the notion that many manufacturing firms have initiated leadership, work design, organization structure, and HRM interventions to compete in the next century while many serrice firms lag behind regarding these changes. The bulk of the Classic Operations firms also tend to be small (i.e., less than 500 employees). and many are strug- 
Combination

This organization is a large $1>5.000$ employees) operating division of a Fortune 100 firm engaged in the design and production of components for the aerospace industry: It initiated aggressive quality and cost containment programs in the production. staff. and sales departments while focusing on both cash cow and new product developments within engineering. This resulted in an operating stalemate among the various departments that was not resolved by management. Due to its prestige, the firm historically had no trouble attracting employees. Therefore. its staffing and development capabilities were minimal for an organization this size. In addition. local HRW initiatives dealing with teaming, diversity: appraisal, and pay-for-performance had vague objectives owing to the divergent strategic objectives throughout the facility: These practices were also tentative and muted due to constant squabbles with the corporate headquarters HR staff and a local management team focused on cost containment as the core profit engine.

\section{Classic Operations}

This "classic operations" firm is a nationwide nonprofit organization with operations in major U.S. cities. The individual operations are very cost focused while attempting to provide at least moderate quality service to its clientele. HRM practices are practically nonexistent as local management attempts to recruit, hire, motivate, reward, and develop employees based only on guidelines from the national office and in a context of dwindling budgets. Discussions with these managers reveal an interest in building at least minimal HRM practices. but little time and expertise to accomplish the
task.

\section{Emerging Operations}

An excellent example of an "emerging operations" organization is a moderate sized (about $500 \mathrm{em}$ ployees) manufacturing firm producing metal and plastic components for several Fortune 100 businesses. The distinguishing feature of this company is its use of a highly efficient cost-oriented production process embedded in a culture of strong spirituality and respect for individual employees. The firm has created selection, orientation, development, diversity: and reward practices with the Judeo-Christian philosophy emphasizing love and respect for one s work. co-workers, customers, suppliers, and company. Finally, the senior management team takes the lead in fostering both the operating culture and HR practices that support the spirituality within the firm.

\section{Classic Product Leader}

This example organization is an 800 person operating division of an international firm. It designs and produces various components and devices for the medical industry. It is a world leader in several product areas developed at this facility. The firm is operated by an enlightened local management team enjoving minimal interference from corporate headquarters. The operations, engineering, and marketing departments are integrated into product and customer oriented teams that are supported by extensive technical, social, and financial training and a pay-for-performance system measuring product quality and customer satisfaction and consisting of merit pay pegged above local market conditions and a bonus system reaching to the operator level. Staffing efforts are nationwide, even for technical positions. and are conducted by individual teams with support from the HR Department. In addition, the firm has formed provider relationships with several agencies to ensure access to temporary emplovees with appropriate skills.

\section{Classic Customer}

This organization is a moderately sized (600 employees) medical center specializing in the treatment of heart and lung aliments. The firm revolves around a core group of physicians, nurses, and technicians, who provide world-class treatment in their specialty areas. Nonmedical personnel are selected on the basis of their social and project management capabilities. Teams of medical and nonmedical personnel are organized around client groups and treatments. They provide a wide range of services designed to relieve clients of pre- and post-treatment concerns dealing with insurance, long-term aftercare, return to work/life. etc. While the team members are paid based on their professional designations, liberal nonfinancial rewards are used by administrators to signal superior client service and bonuses are distributed based on patient feedback. 
gling financially. As a result, they are beginning to seek alliances and other strategic initiatives to reposition themselves for the future. Morale often tends to be low, however, and employees openly question management's vision for the future.

\section{Energing Operations}

This configuration is comprised of organizations competing in a fairly stable environment (i.e., slowing changing customer bases, modes of competition, prices, and technology within a market) using an operational excellence competitive strategy. What is different about these organizations, however, as compared to Classic Operations firms is their strong reliance on the HRM practices of staffing, development, involvement, and rewards. These firms tend to have rigorous staffing practices led by line personnel and focused as much on cultural factors as on job skills. Staffing activities are designed to educate applicants regarding the firm's culture and to make it difficult to enter the organization. Employees are organized into product/customer teams and supported by technical, social, and leadership training. An appreciation of diversity; within the core features of the organization culture and for the purpose of competitive advantage. is an operating norm. Reward practices in these firms tend to focus on the use of liberal nonfinancial incentives, at or above market base pay, and bonus systems driven down to operating personnel. Finally, these organizations make sparing use of temporary personnel and only for the lower level job families. All these practices are fully supported by a management team that spends as much time dealing with human resources as with plant, equipment, and financial issues.

In general, these firms are in the manufacturing sector, tend to be fairly large (500 to 2.500 employees), are highly effective in the areas of resource acquisition, operational efficiency; product/service quality; change, coordination, and development of human resources, and produce above industry average financial results.

\section{Classic Product Leader}

Organizations in this configuration compete in a dynamic environment (i.e.. rapidly changing customer bases, competitive tactics, channels of distribution, prices, and use of technology within a market) and utilize a definite product leader market strategy: Product innovation is supported by strong practices throughout the four HRM dimensions. These organizations tend to have a well-developed staffing philosophy and procedures supplemented by a clearly defined temporary employee strateg: Most of these organizations have developed preferred provider arrangements with local employment agencies and utilize parttime employees within all job families except management. The greatest support for product innovation, however, comes from the use of competency-based development activities and cross-functional teams working in a total quality management culture. These teams are typically buttressed by assistance programs (e.g., counseling, fitness, and workhome initiatives), diversity training, flexible benefit packages. developmentally oriented appraisals, and performance focused rewards such as bonuses and various nonfinancial incentives. In addition, the senior management team firmly believes in people with valuable know:how as a competitive weapon and plays an active role in ensuring the integration of people issues with all marketplace initiatives.

Our experience show's that many of the organizations in this configuration are large manufacturers (i.e., 500 to 5.000 employees) that both are operationally effective and achieve above average financial results.

\section{Classic Customer}

These organizations compete in a very dynamic environment (i.e., marked by constant change in customer bases, competitive tactics, channels of distribution, prices, and use of technology' within a market) and use a customer intimacy strategy to differentiate themselves from their competitors. The customer strategy is supported by intense staffing and development practices designed to identify highly social and innorative applicants and train them regarding the company's products/ serrices, customers' needs. and client relationships. Staffing and development activities are further reinforced by job designs that include cross-functional product and customer based 
teams, wide discretion for customer problem solving at the lowest levels of the organization. Wage compression to foster teamwork. and bonuses based on customer service. These firms tend to restrict their use of temporary personnel to support positions that do not interact directly with customers. Finally, senior managers strongly believe that the quality of their employees is a key competitive advantage and spend a great deal of time integrating operating and people issues.

This configuration contains fewer organizations than do the other groupings. The bulk of these firms are service-related, vary consistently from small to large in size, and are above average in operating effectiveness and financial results.

\section{Use of the Framework and Implications for HR Managers}

\section{Diagnosis}

The framework is a diagnostic tool when used in strategic planning to integrate marketplace and people issues into a comprehensive schema. It provides a conceptual roadmap for line and HR managers to describe, understand. and come to agreement regarding the key components that influence the operating culture of the organization. By focusing on each component and describing its relationship to the others, an in-depth picture emerges regarding how human assers are being deployed in support of marketplace initiatives and the role management plays in orchestrating the entire system.

Human resource managers, however, must acquire a knowledge of the concepts and language describing operating environments, financial indices, competitive strategies, leadership, and human resource philosophy, in addition to tactical HRM practices. The systems nature of the configurations demands a sensitivity to the relationships and the incentives that sustain them. which exist among the components. and a comfort level with answering questions such as "What does it mean for our pay practices if the industry becomes more chaotic and we need to change operations at a faster and faster pace?" Sys- tems thinking forces a recognition of the harmony that exists among the system components as they interact to produce something emergent. something more than the components themselves, and with the larger competitive world within which the firm operates (.Acloff, 1981). HR managers who are uncomfortable with the multiplicity and complexity that accompanies the configuration framework will not be able to help line managers perceire, understand. and influence the often non-linear interactions occurring among the system components.

\section{Informing Trade-Offs}

A critical function of any management team is to make short-term decisions regarding trade-offs among components of the system. As operating environments change or competitive strategy is revised to reposition a firm, decisions must be made regarding leadership actions and HRM practices in support of the repositioned company. The framework provides a mechanism for management to view the component interactions and determine how trade-offs among the components should be made at any point in time. For example, a particular market action may require an infusion of new skills into the organization on a temporary basis. Staffing and reward practices may be altered for a given period of time to attract and retain individuals with specific high leverage competencies. By using the configuration framework, managers may place this action into perspective, determine its long-term effects on the organization, and use that information to communicate the rationale for the action to employees. By placing trade-offs within the context of a larger system, their short-term effects are better understood in terms of their contribution to the firm's mission and long-term strategy. In addition, the trade-offs result in the creation of new outcomes for the firm that strengthen the entire system.

\section{Long-Term Alignment}

Configurations tend to emerge over time as decisions are made regarding the individual components and their interactions. Once configurations are in place and employees are aware of them, they become a double-edge

\author{
As operating \\ environments \\ change or \\ competitive \\ strategy is reised \\ to reposition a \\ firm, decisions \\ mintust be made \\ regarding \\ leaderslizp \\ actions and \\ HRM practices \\ in support of the \\ repositioned \\ conipan.
}


In summar; organizations are complex systems impacted by both caternal (c.g., industry structure) and internal forces (e.g.. sentior ilanagement values regarding people as a competitive advantage, decisions regarding competitive practices, structure, and HRM practices, etc. sword. On the one hand, they serve to provide a rallying culture for the organization. Employees come to recognize the interrelationships among the system components and the implications for their everyday behaviors. On the other, they create a stability that may pose serious transformation problems when industries migrate to newer aspects of customer value. HR managers may use the configurations as a discussion mechanism with line management to determine which of a limited number of configuration schemes makes sense for the organization at the present and into the future and what challenges are posed by movement from one pattern to another. In this way, the HR function is placed at the center of strategic change initiatives and its personnel max plan, communicate, and execute change actions in an anticipatory rather than reactive manner.

A key constraint, however, of successful long-term alignment concerns the degree of variet or flexibility possible within the system. Ashby's law of requisite variety (Heylighen. 1992) notes that a system can only control something in its environment to the extent it has sufficient internal variety to represent the diversity found in the outside world. As a change agent, the HR manager must straddle the line betw'een complete adherence to a strong corporate culture on the one hand and the ability to recognize and move the system to a new configuration when customer value migration occurs. In other words, by using the systems perspective, the HR manager opens the firm to its environment and ensures that a diversity of perspectives and issues are included when trade-offs are made among system components and that employee adaptability becomes a core competency of the organization (Ackoff. 1981).

The systems nature of the configurations warns the HR manager that changes in policy or practice. either business or HRM oriented, cannot be made in a vacuum. For an organization to experience and capitalize on the emergent properties of a configuration (i.e., that state where the whole is greater than the sum of its parts) a tight alignment among the components is necessan: At a micro level, this means that HRII practices must be developed and implemented with a common rision and a full under- standing of all line and HR personnel. Constructing a rewards package or a human diversity initiative, for example, without regard for other HRM endeavors will result in less than optimum performance on the part of the organization. Also, an HRM philosophy and strategy that takes little consideration of environmental dynamics, competitive positioning, and management team values regarding employees will not contribute to a tightly bound configuration with positive emergent properties for competitive advantage.

\section{Summary}

Organizations tend to form configurations based on their operating environment, competitive position, HRM practices, and management support for HRM. Furthermore, these patterns appear to be stable and differentially related to organization effectiveness.

Through observation we have identified several high frequency configurations. These systems represent typical ways in which organizations have aligned their marketplace and internal actions to compete in their industries. We also discovered several interesting features of these configurations. They were rarely planned in advance. Rather they emerged over time as senior managers made decisions about posturing their organizations within the competitive environment. As managers' knowledge and experience with a particular configuration grew, so did their awareness of its strengths and weaknesses and their ability to make shortterm adjustments to the relationships among the system components. The configurations had an organizing quality in that as ther were recognized by firm members, they provided a rallying concept for operating the company. Finally; once they had emerged and been recognized, changing them required a new rision and a large burst of energy resulting in dramatic movement to a new configuration.

In summary, organizations are complex systems impacted by both external (e.g. industry structure: Porter, 1985) and internal forces (e.g., senior management values regarding people as a competitive adrantage. decisions regarding competitive practices. structure, and HRM practices, etc:; Miles \&- Snow; 1994). These forces interact over time resulting in realized configurations that have discernible ef- 
fects on organization effectiveness. Only by studying these systems holistically and attempting to untangle the interactions among the external and internal variables through time does a true picture emerge regarding organization ef- fectiveness, a picture that will help both the theorist and practitioner advance understanding and action in organizations.

Michael A. Sheppeck is Associate Professor in the Department of Management. Unirersity of St. Thomas. Prior to joining St. Thomas, he was the Director of Organization Development for Honeywell Inc. He holds a Ph.D. from the University of South Florida in Industrial/Organizational Psycholog:: Dr. Sheppeck teaches, writes, and consults in the areas of strategic human resource management and HR system design.

JACK MILITEllo is Associate Professor in the Department of Management, University of St. Thomas. Prior to joining St. Thomas. he was the Manager of Cost Reduction and Administration for Conrail. He holds a Ph.D. from the Wharton School, University of Pennsylvania, in Social Systems Sciences. Dr. Militello teaches, writes, and consults in the areas of business strategy and change.

\section{REFERENCES}

Ackoff, R.L. (1981). Creating the corporate future. New York: John Wiley \& Sons.

Andrews. K.R. (1987). The concept of corporate strategy. Homewood, IL: Irwin.

Arthur, J.B. (1994). Effects of human resource systems on manufacturing performance. Academy of Management Journal, 37, 670-687.

Arthur, J.B. (1992). The link between business strategy and industrial relations systems in American steel minimills. Industrial and Labor Relations Review, 45. 488-506.

Blackburn, R.. \& Rosen, B. (1993). Total quality and human resources management: Lessons learned from Baldrige Award-winning companies. Academy of Management Executive, 7, 49-66.

$\mathrm{CCH}$ Inc. (1995). Human Resource Management: Ideas and Trends in Personnel, Issue 356.

Delaney; J.T.. \& Huselid, M.A. (1996). The impact of human resource management practices on perceptions of organizational performance. Academy of Management Journal, 39, 949-969.

Delaney. J.T., Lewin. D., \& Ichniowski, C. (1989). Human resource policies and practices in American firms. Washington, DC: U.S. Government Printing Office.

Delery, J.E.. \& Doty, D.H. (1996). Modes of theorizing in strategic human resource management: Tests of universalistic, contingency, and configu- rational performance predictions. Academy of . Management Journal, 39, 802-835.

Dyer, L., \& Holder, G.IV. (Eds.) (1988). Human resource management: Evolving roles and responsibilities. Washington, DC: The Bureau of National Affairs, Inc.

Galbraith. J.R. (1983). Strategy and organization planning. Human Resource Management, 22, 63-7.7.

Hambrick, D.C., \& Snow, C.C. (1987). Strategic reward systems. In C.C. Snow (Ed.), Strategy, organization design, and human resource management. Greenwich, CT: JAI Press, 68-96.

Hammer. MI., \& Champy, J. (1993). Reengineering the corporation: A manifesto for business revolution. New York: Harper Business.

Heylighen, F. (1992). Principles of systems and cybernetics: An evolutionary perspective. In R. Trappl (Ed.), Cybernetics and Systems '92. Singapore: World Science, p. 3-10.

Huselid, M.A. (1995). The impact of human resource management practices on turnover, productivity, and corporate financial performance. Academy of Management Journal, 38, 635-672.

Kochan. T.A., \& Chalykoff, J. (1985). Human resource management and business life cycles: Some preliminary propositions. Paper presented at the Conference on Human Resources and Industrial Relations in High Technology Firms. Los Angeles, March. 
Kochan. T.A., McKersie. R. B., \& Cappelli, P. (1984). Strategic choice and industrial relations theory. Industrial Relations, 23, 16-39.

MacDuffie. J.P. (1995). Human resource bundles and manufacturing performance: Organizational logic and flexible production systems in the world auto industry. Industrial and Labor Relations Review, $48,197-221$.

Mever, A.D.. Tsui.A.S. \& Hinings, C.R. (1993). Configurational approaches to organizational analysis. Academ! of Management Journal, 36, $1175-1195$.

Miles, R., \& Snow; C. (1994). Fit, failure, and the hall of fame: How companies succeed or fail. New Iork: Free Press.

Miller, D. (1988). Relating Porter's business strategies to environment and structure: Analysis and performance implications. Academy of Management Journal, 31, 280-308.

Miller, D. (1987). The genesis of configuration. Academy of Management Review: 12. 686-701.

Miller, D.. \& Friesen. P.H. (1984). Organizations: A quantum view. Englewood Cliffs. XJ: PrenticeHall.

Mintzberg. H. (1989). Mintzberg on management: Inside our strange world of organizations. New lork: The Free Press.

Pfeffer, J. (1994). Competitive advantage through people. Boston: Harvard Business School Press.

Porter, M.E. (1985). Competitive advantage. New York: The Free Press.

Quinn, R.E.. \& Rohrbaugh, J. (1983). A spatial model of effectiveness criteria: Towards a competing values approach to organizational analysis. Management Science. 29, 363-377.

Reve, T. (1990). The firm as a nexus of internal and external contracts. In M. Aoki. B. Gustafsson. \&
O.E. Williamson (Eds.), The Firm as a Nexus of Treaties. Newbury Park, CA: Sage.

Schuler, R.S. (1992). Linking the people with the strategic needs of the business. Organizational Dynamics, Summer, 8-32.

Schuler, R.S., \& Jackson, S.E. (1989). Determinants of human resource management priorities and implications for industrial relations. Journal of Management, 15, 89-99.

Tichy, N.M., Fombrun, C.J., \& DeVanna, M.A. (1982). Strategic human resource management. Sloan Management Review, Winter, 47-61.

Treacy, M. \& Wiersema, F. (1995). The discipline of market leaders: Choose your customers, narrow your focus, dominate your markets. Reading. MLA: Addison-Wesley:

Ulrich, D., \& Lake, D. (1990). Organizational capability: Competing from the inside out. New Tork: John Wiley \& Sons.

Wright, P.M., McCormick, B., Sherman, S.. \& McMahan, G. (1996). The role of human resource practices in petro-chemical refinery performance. Paper presented at the 1996 Academy of Management Meeting, Cincinnati, $\mathrm{OH}$.

Wright, P.M., \& McMahan, G.C. (1992). Alternative theoretical perspectives for strategic human resource management. Journal of Management. 18. 295-320

Wright, P.M., \& Snell. S.A. (1991). Toward an integrative view of Strategic Human Resource Management. Human Resource Management Review: 1, 203-225.

Youndt, M.A., Snell, S.A.. Dean, J.W., \& Lepak. D.P. (1996). Human resource management, manufacturing strateg; and firm performance. Academy of Management Journal, 39, 836-866. 